\title{
Investigating Instructors' Attitude towards the Adoption of E- Learning Technology in Libyan Higher Education Institutes: Case Study; Misurata University
}

\author{
Khalid Ramadan $^{1}$, Jamal Elatresh $^{2}$, Alzain Alzain ${ }^{3}$, Umit Tokeser $^{4}$ \\ ${ }^{1}$ Department of Computer Science, Institute of Materials and Engineering, Kastamonu University/Turkey \\ ${ }^{2}$ Department of Computer Science, Institute of Materials and Engineering, Kastamonu University/Turkey \\ ${ }^{3}$ Department of Computer Science, Faculty of Education, Misurata University/Libya \\ ${ }^{4}$ Department of Mathematics, Faculty of Science and letters, Kastamonu University/Turkey
}

Correspondence Author: Khalid Ramadan, Department of Computer Science, Institute of Materials and Engineering, Kastamonu University/Turkey E-mail: kramadan@ogr.kastamonu.edu.tr

Received date: 18 March 2019, Accepted date: 5 May, Online date: 25 May 2019

Copyright: (C) 2019 Khalid Ramadan et al., This is an open-access article distributed under the terms of the Creative Commons Attribution License, which permits unrestricted use, distribution, and reproduction in any medium, provided the original author and source are credited.

\begin{abstract}
In recent years, Higher Education Institutes (HEIs) worldwide have invested heavily in the adoption of e-learning with a view to improving the quality of their education. However, the success of their development faced numerous challenges, particularly, the end user's acceptance, including the perceptions, and engagement. Therefore, surveying lecturers' attitudes toward e-learning in LHEIs is considered to be a meaningful stage before thoroughly embarking e-learning practices in educational activities.

Instructors' attitudes towards the use of e-learning have been extensively investigated in the educational system worldwide, however, in Libya, this research is ineffective and limited. In light of this, the present study aims to investigate the perception of instructors' in LHEIs and their attitudes towards implementing e-learning technology, where an online questionnaire has been utilized to collect data from 219 academic staff in various faculties at Misurata University (MU), in Libya. The collected data were analyzed using Statistical Package for Social sciences (SPSS) to investigate the impact of demographic characteristics of participants on their attitude towards e-learning. The study concluded with a set of findings that revealed that the demographic characteristics of participants might have a significant impact on their attitude towards e-learning; which may directly impact the success of e-learning adoption in higher education. The results also show that the instructors in LHEIs have a positive attitude towards elearning.
\end{abstract}

Keywords: E-learning success, instructors' attitude, academic teaching' satisfaction, information, and communication technology.

\section{INTRODUCTION}

The presence of e-learning technology has become more and more apparent in the entire teaching and learning process over HEIs worldwide. However, although the implementation of e-learning initiatives has increasingly grown and accepted in advanced societies, it is still in its formative years in many developing countries such as Libya(Elkaseh, Wong, \& Fung, 2015; T. Kenan \& Pislaru, 2012; Tamtam, Gallagher, Olabi, \& Naher, 2011). This was supported by Rhema and Miliszewska who reported that Libyan Higher Education Institutes (LHEIs) are still struggling with conventional face-to-face of teaching and learning method (Othman, Pislaru, Kenan, \& Impes, 2013; Rhema \& Miliszewska, 2010).

With reference to HEIs in developing nations, they have lagged behind those in the industrialized globe, chiefly due to several socio-economic challenges and obstacles(Bahiti \& Farizi, 2018; Bhuasiri, Xaymoungkhoun, Zo, Rho, \& Ciganek, 2012; Idris \& Osman, 2017; Thuraya Kenan, Pislaru, \& Elzawi, 2014; Rhema \& Miliszewska, 2010; Tarus, Gichoya, \& Muumbo, 2015).

The amalgamation of e-learning technology in HEIs is often a complicated process and is influenced by various aspects and drivers. Those challenges are linked to the crucial issue regarding the acceptance and effectiveness of delivering instructional materials and teaching activities as well as end-user satisfaction(Pilli, Fanaeian \& Al-Momani, 2014). In this context, (Xhaferi, Farizi \& Bahiti, 2018b) stated that successful incorporation of ICT in education environment heavily relies on the teaching staff' attitudes. Thus, they have been recognized as a vital determinant for the effective ICT deployment in education experience(Sife, Lwoga \& Sanga, 2007). Additionally, as stated by Al- Adwan stakeholders' engagement and the end-user acceptance to e-learning 
Citation: Khalid Ramadan, et al., Investigating Instructors' Attitude towards the Adoption of E-Learning Technology in Libyan Higher Education Institutes: Case Study; Misurata University. Australian Journal of Basic and Applied Sciences, 13(5): 43-54. DOI: 10.22587/ajbas.2019.13.5.5

technology as well as their satisfaction are the most crucial step for meaningful and useful integration(Al-Adwan, Al-Adwan \& Smedley, 2013).

Currently, Libya puts a significant emphasis on development in every aspect of life, as well as the education system throughout the country. Therefore, the Ministry of Education has emphasized the importance of integrating e-learning technology into education and considered as a promising tool in re-developing and flourishing the education sector. In this essence, as academic staff been the pivotal stakeholders of all education process, many studies indicated that the practical application of teaching and learning technology depends chiefly upon the attitudes of teaching staff, who ultimately judge on whether to embrace or ignore it for their educational activities(Kisanga, 2016; Rogers, 2003; Xhaferi, Farizi, \& Bahiti, 2018). In light of this, instructors' perception, attitude, and experiences have to be sought and put in place in the LHEIs system, and also academic staff engagement and acceptance must be taken into account. With this concept, the objective of this study is to explore fully the role of academic staff's in e-learning usage at MU. Therefore, tutors were requested to answer an online survey for exploring their attitudes.

The findings of this research may help the LHEIs to generate a paradigm for e-learning implementation and may reduce the gap in knowledge by inserting a valuable addition to the field of e-learning development in Libya and subsidizing the teaching and learning process.

\section{Research Objectives and Questions}

The overall goal of the present research is to analyze academics' attitude towards e-learning in MU. The following are research questions that guided the study;

1. What are instructors' perceptions and attitudes towards the deployment of e-learning in the process of teaching and learning?

2. Is there any association between demographic characteristics, including teaching experience, age, gender, computers use, academic area, and tutors' attitude towards e-learning?

\section{LITERATURE REVIEW}

Over the past twenty years, the trend of using e-learning has been widely increased in the educational field and has become an integral part of the successful learning and teaching process in many parts of the world. In this essence, Kwofie \& Henten stated that it offers a new technique of learning and teaching and has the potential to enhance the education sector (Ahmed, 2013; Kwofie \& Henten, 2011) The widespread of harnessing ICTs in education activities implies that conventional learning and teaching methods no longer fit with the global trend in the education system (Ahmed, 2013; Othman, 2009). Therefore, HEIs worldwide, in particular, developing States seeking to embrace e-learning in their higher education to improve and enhance the learning and teaching process, but still faces a number of impediments and challenges such as, individual, institutional, and technological challenges (Al-Azawei, Parslow, \& Lundqvist, 2016; Andersson \& Grönlund, 2009).In this token, addressing those challenges requires a sound understanding of the stakeholders' perception and attitudes, in particular, educators as a significant determinant or prerequisite for any successful e-learning initiatives(Ahmed, 2013; Liaw, Huang, \& Chen, 2007).

In line with a number of studies, one of the most significant challenges that encountered the successful deployment of elearning technology was the acceptance of academic staff to use it in learning practice (Ahern \& Wink, 2010; Kisanga, 2016; Teo, Ursavaş, \& Bahçekapili, 2012; Yilmaz \& Bayraktar, 2014). Similarly, strong support can be found for this argument by many research studies that demonstrated that a teaching member's active involvement, positive attitude, perception, and engagement greatly enhance the success of e-learning adoption in educational activities (Weller, 2007; Pynoo et al., 2012; Rhema, Miliszewska and Sztendur, 2013). This was also supported by Suri who stated that the successful development of elearning technology in education environment largely relies on academic staff attitudes toward embracing this technology in education activities (Teo, 2011; Suri and Sharma, 2013; Suri and Sharma, 2016). Additionally, in 2007, Selim confirmed that instructor characteristic is regarded to be a critical success factor (CSF) of e-learning deployment (Selim, 2007).In this token, instructors' experiences, expectations, and thoughts highly recommended to be efficiently investigated fully implementing elearning practices in educational activities.

To sum up, instructors are considered to be the fundamental stakeholder of e-learning. Therefore, their attitudes, readiness, and willingness immensely influence their adoption of it into teaching and learning activities. In this essence, the instructor's positive attitude towards e-learning may provide useful insight about integrating technology into teaching and learning process successfully.

\subsection{E-LEARNING Concept:}

Although several definitions of e-learning technology are provided by several researchers, there is no specific universal definition that has been determined. Therefore, many studies have presented a wide range of definitions for e-learning from different perspectives. In light of this, Sangra (2011) defined e-learning as the of ICT tools such as computers, software, and Internet in the process of teaching and learning experience in the educational area ( a Sangrà, Vlachopoulos, Cabrera, \& Bravo, 2011; A. Sangrà, Vlachopoulos, \& Cabrera, 2012). In the same way, it was defined by Welsh (2003) "E-learning can be defined as the use of computer network technology, primarily over an Intranet or through the Internet to deliver information and instruction to individuals" (Welsh et al., 2003, p.246). Additionally, Rhema (2011) pointed out that e-learning is an intelligent learning environment using contemporary tools of ICT, through the effective amalgamation of ICT and the instructional materials to accomplish, a cutting-edge learning environment which may thoroughly enrich the traditional teaching experience 
Citation: Khalid Ramadan, et al., Investigating Instructors' Attitude towards the Adoption of E-Learning Technology in Libyan Higher Education Institutes: Case Study; Misurata University. Australian Journal of Basic and Applied Sciences, 13(5): 43-54. DOI: 10.22587/ajbas.2019.13.5.5

( Li, Cheng, \& On, 2008; Rhema \& Miliszewska, 2010). In the same token, Mason reported that "the e-learning is the effective learning process created by combining digitally delivered content with (learning) support and services" (MASON, R. \& RENNIE, 2006, p.13-15). In general, e-learning is new technology refers to the use of Information Technology and its applications, including computer networks, interactive media, digital technologies, and the internet regardless of place and an an time to enrich teaching and learning experiences by offering up-to-date technique of delivering education.

\subsection{Impact of E-learning Adoption in Education}

The increasing demand for ICTs, in particular, e-learning in the education sector encouraged HEIs to reevaluate and modernize their education systems and makes the e-learning the major factor in their education process. This trend was supported by Xhaferi, who reported that the e-learning adoption had had a vital effect on the methodology of teaching, gaining knowledge, learning experiences and instructional materials (Xhaferi et al., 2018). In light of this ,e-learning has become to be a spirited component of the up-to-date education system worldwide, where it is likely to be a promising technique in improving the education experience, meeting learners' needs, addressing the shortage of qualified academic staff, building learners' capabilities and laying the foundation for better learning and teaching experience(Andersson and Grönlund, 2009; Rhema and Miliszewska, 2010). Additionally, e-learning technology represents more than just employing ICT to supply cutting-edge learning and teaching experience but also acquiring learners' knowledge and meeting diverse stakeholders requirements (Denis, 2014; Flood, 2002). Therefore, educators of all ages and abilities can develop their capabilities; learn on their own and at their own pace anywhere, at any time (Flood, 2002).

Generally, e-learning is becoming progressively an integral part of the HEIs curriculum learning, and it also authorizes learners to join and interact with each other, and with their educators, to hand out and discuss curricula a more flexible and productive manner. Therefore, e-learning is one of the most critical technologies that can support and enhance the education process by acquiring new knowledge as well as offering an effective learning environment (Dečman, 2015; Xhaferi, Farizi and Bahiti, 2018a).

\subsection{Teachers' Attitudes toward e-learning.}

The success of e-learning implementation is influenced by a variety of factors, including perceptions about and attitudes toward the use of e-learning in learning and teaching. To effectively amalgamate educational technology in educational activities should be promoted heavily by the instructors' perspectives. Consequently, the positive attitude of lecturers towards technology hugely determine their adoption and harness of technology into their teaching (Xhaferi et al., 2018). This was also supported by Sife (2007), who reported that positive attitude towards ICTs is widely perceived as a significant issue for the efficient deployment on education environment (Sife et al., 2007). In the same token, Tuparova (2006) also affirmed that the academic staff has a positive attitude towards harnessing of ICTs facilities such as computer use and the internet in their teaching activities. However, a remarkable variation exists in instructors' tendency to evolve and harness e-courses based on teaching experience (Tuparova, Tuparov, Ivanov, Karastranova, \& Peneva, 2006).On the other hand, Bakr (2011) pointed out that instructors have a positive attitude towards computer use in their work and also informed that there were no essential differences in terms of gender and teaching experience among the academic staff (Bakr, 2011) Additionally, a number of studies revealed that the deployment of e-learning is seen to be efficacious if it fulfills the aspirations, meets the needs, and tackles with the concerns of its stakeholders (Wagner et al., 2008; Elliott and Clayton, 2007; Clayton et al., 2008; Miliszewska, 2009; Rhema, Miliszewska and Sztendur, 2013).

It is evident that stakeholders, especially, instructors, will perceive e-learning technology as valuable technique if they realize that it would support them to develop their teaching effectiveness and proficiency. Generally, the attitude is the main driver for instructors to intend to use the e-learning technology in the education experience.

\section{METHODOLOGY}

The target population was academic staff from various faculties of the MU. Accordingly, 219 instructors were invited to answer an online version of a questionnaire for investigating their attitudes and perceptions towards the deployment of e-learning in teaching and learning. The empirical research approach has been applied in this study included the activities of data collection from the study sample. Also, some data analysis techniques were used to obtain descriptive statistical indicators for the study sample. Statistical Package for Social sciences (SPSS) was used to analyze the collected data.

\subsection{Data collection stage}

The study used the survey methodology and as it was based upon the questionnaire distributed to the teachers to assess their attitudes towards e-learning and to find out any demographic factors that are significant towards the teaching staff ' use of elearning. A five-level Likert scale questionnaire was designed and distributed to achieve the study aim. The sample size under study involved instructors from all the major faculties of MU The format of the questionnaire, used in this study enabled participants to select one of the following alternatives:"1"'strongly disagree', "2" 'disagree', "3" 'neutral', "4" 'agree', "5" 'strongly agree', to indicate to what extent they are satisfied with each statement related to their attitude towards e-learning in learning/teaching process. 


\subsection{Statistical analysis}

To investigate the research hypothesis, the responses of 219 participants were collected using an online questionnaire, and then analyzed using the Statistical Package for Social sciences (SPSS).

To check the independence between gender of instructors and the attitude towards e-learning Chi-square was applied. And then the Person correlation test was applied to check the association among the different variables such as participants age, computer use, and teaching experience.

\section{RESULT}

This research used a survey method to examine the perception of teachers towards e-learning.

The first section discusses teachers' demographic characteristics, i.e., gender, age, qualifications, teaching experience, faculty, and academic sector. The second section examined the perception of teachers towards e-learning. Finally, analysis of the effect of demographic characters on the perception of teachers towards e-learning.

\section{A. Demographic Characteristics of Teaching Staff Members}

The total number of participates was 219 tutors from all the major faculties of MU. The results revealed that about (64\%) the instructors involved in the survey were male, whereas $(36 \%)$ were females.

According to qualifications, (42.9\%) of respondents had a Lecturer's degree, (28.4\%) an Assistant Lecturer's degree, ( $9.5 \%)$ had an Assistant Professor, ( $7.4 \%$ ) had an Associate Professor and (11.8\%) had a Professor degree. In terms of teaching experience, the result revealed that there were (52\%) tutors with teaching experience less than ten years and (33.3\%) tours with teaching experience from 11 to 25 years whereas (14.6\%) more than 25 years of teaching experience. Data on the academic area indicated that about $(57 \%)$ of respondents with science discipline whereas $(43 \%)$ with art discipline. Further information on instructors' computer use, showed that there were (52.2\%) educators with computer use experience less than ten years and (34.2\%) tutors with computer use experience ranging from 11 to 25 years whereas (13.6\%) more than 25 years of computer use experience. Table 1 shows the demographic characteristics of the participants.

Table1: Demographic Statistics of participating instructors

\begin{tabular}{|c|c|c|c|}
\hline $\begin{array}{l}\text { Demographic } \\
\text { Characteristics }\end{array}$ & Descriptive Statistics & Respondents & Percentage $\%$ \\
\hline \multirow[t]{3}{*}{ Academic sector } & science & 124 & $57 \%$ \\
\hline & Arts & 95 & $43 \%$ \\
\hline & Total & 219 & \\
\hline \multirow[t]{9}{*}{ Faculty } & IT & 50 & $22.9 \%$ \\
\hline & Education & 30 & $13.7 \%$ \\
\hline & Engineering & 38 & $17.4 \%$ \\
\hline & Arts & 27 & $12.4 \%$ \\
\hline & Science & 34 & $15.5 \%$ \\
\hline & Law & 6 & $2.7 \%$ \\
\hline & Medicine & 8 & $3.6 \%$ \\
\hline & Economics and Business & 26 & $11.8 \%$ \\
\hline & Total & 219 & \\
\hline \multirow{3}{*}{ Gender } & Male & 140 & $64 \%$ \\
\hline & Female & 79 & $36 \%$ \\
\hline & Total & 219 & \\
\hline \multirow[t]{4}{*}{ Age } & Less than 35 & 29 & 13.2 \\
\hline & Between 36-50 & 170 & 77.7 \\
\hline & More than 50 & 20 & 9.1 \\
\hline & Total & 219 & \\
\hline \multirow[t]{6}{*}{ Qualifications } & Assistant Lecturer & 62 & $28.4 \%$ \\
\hline & Lecturer & 94 & $42.9 \%$ \\
\hline & Assistant Professor & 21 & $9.5 \%$ \\
\hline & Associate Professor & 16 & $7.4 \%$ \\
\hline & Professor & 26 & $11.8 \%$ \\
\hline & Total & 219 & \\
\hline \multirow{4}{*}{$\begin{array}{l}\text { Teaching } \\
\text { Experience }\end{array}$} & Less than 10 & 114 & $52.1 \%$ \\
\hline & Between 11-25 & 73 & $33.3 \%$ \\
\hline & More than 25 & 32 & $14.6 \%$ \\
\hline & Total & 219 & \\
\hline \multirow[t]{2}{*}{ Computer Use } & Less than 10 & 114 & $52.2 \%$ \\
\hline & Between 11-25 & 75 & $34.2 \%$ \\
\hline
\end{tabular}




\begin{tabular}{|c|c|c|c|}
\hline & More than 25 & 30 & $13.6 \%$ \\
\hline & Total & 219 & \\
\hline
\end{tabular}

Generally, information from Table 1 suggests that the majority of educators in this study were males, aged between 16-35 years, holding Lecturer's degree, with Science discipline, with teaching experience less than ten years, with computer use experience less than 10 years and they belong to IT Faculty.

\section{B. Staff members' perception}

The first research question was, "what are the instructors' perceptions and attitudes towards e-learning?".In this essence, this section analyzes the attitude and perception of teaching staff members towards e-learning adoption at MU.

As the first question asks instructors to respond whether they support the implementation of e-learning in all HEIs in Libya or not.

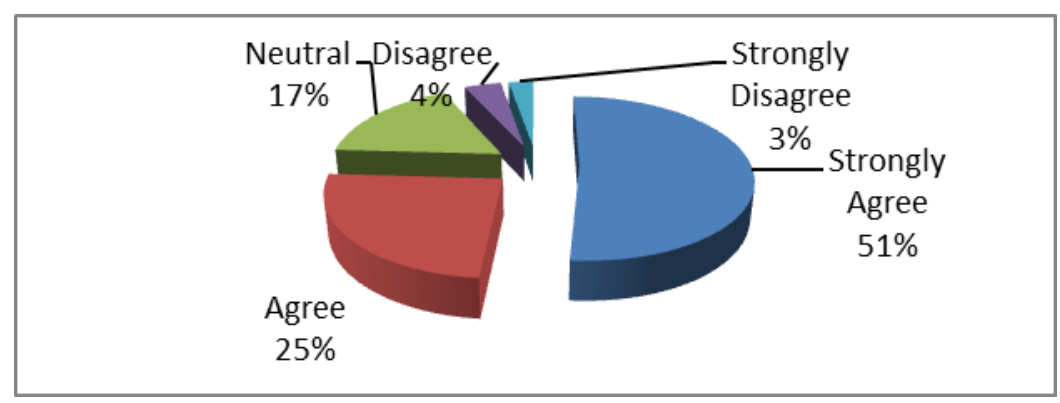

Figure 1: participants' perception of support the implementation of e-learning

The Figure 1 shows that the majority of participants (51\%) responded with strongly agree, and $25 \%$ responded with agreeing was in favor of implementing e-learning in the educational process, while only $4 \%$ of tutors disagree with this statement. This result underlines the participants' encourage the implementation of e-learning.

This study is also inquired about the response of teachers towards using e-learning as a tool for teaching will increase the efficiency of their teaching experience.

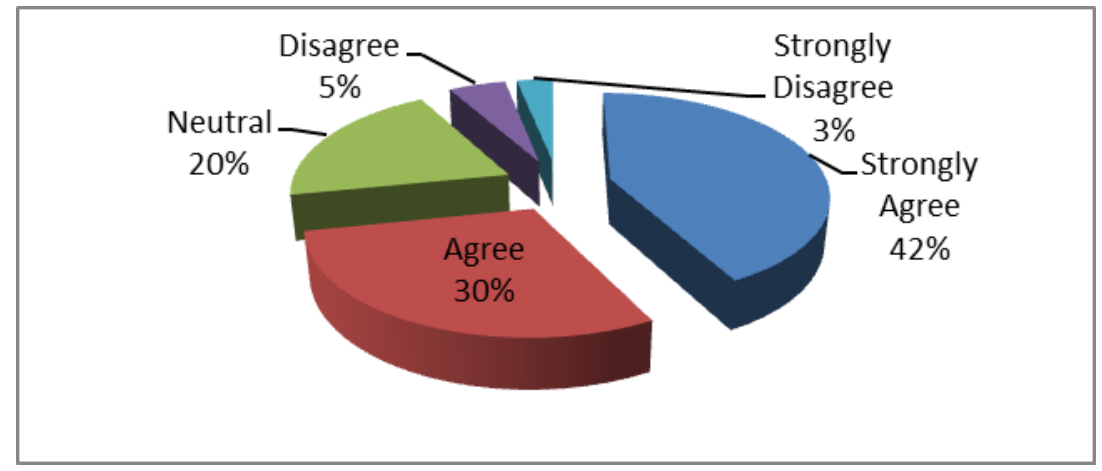

Figure: 2 instructors' response towards using e-learning as a tool for teaching will increase the efficiency of their teaching experience

This result indicates that the majority of teachers, around $72 \%$ strongly agree or agree, and they believed that using elearning as a tool for teaching will increase the efficiency of their teaching experience.

In terms of teachers' perceptions regarding the impact of using e-learning on student performance, the teachers were asked whether they think that the use of e-learning has a positive effect on the performance of the students. 


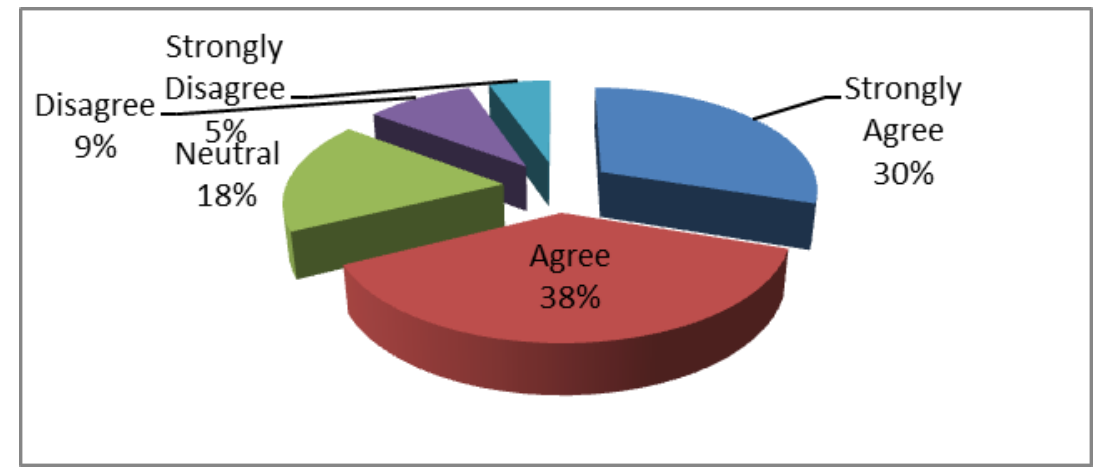

Figure 3: the use of E-learning has a positive effect on the performance of the student

As it is seen, the Figure 3 shows that many tutors $(68 \%)$ agree that e-learning has a positive influence on students' performance, whereas only $14 \%$ felt that e-learning has not a positive effect on the performance of the students.

Concerning student engagement, the teachers were asked whether the use ofe-learning will make the students more engaged in the education process.

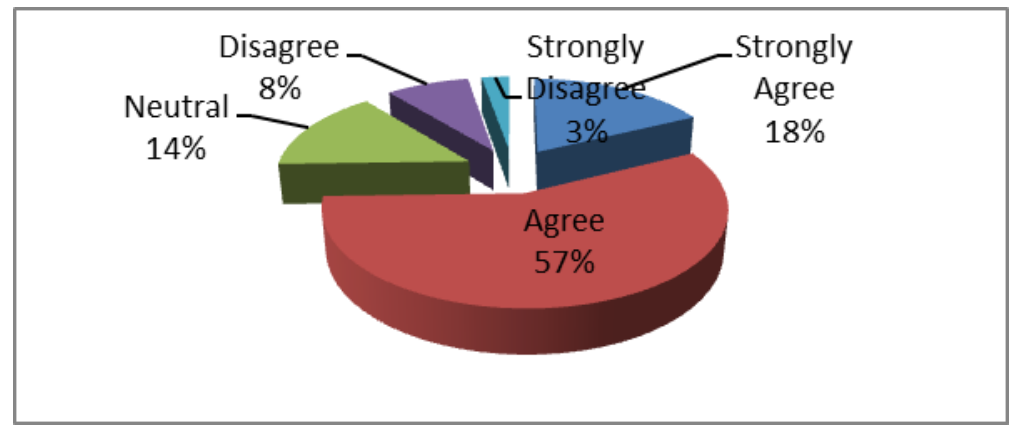

Figure 4: the use of e- e-learning makes the students more engaged in the education process

These statistics in Figure 4 indicate that the majority of participants (75\%) think that e-learning makes the students more engaged in the education process.

Concerning teachers' beliefs about using e-learning as a new method for delivering courses, the teachers were asked whether the use of e-learning is more flexible than the traditional way of teaching.

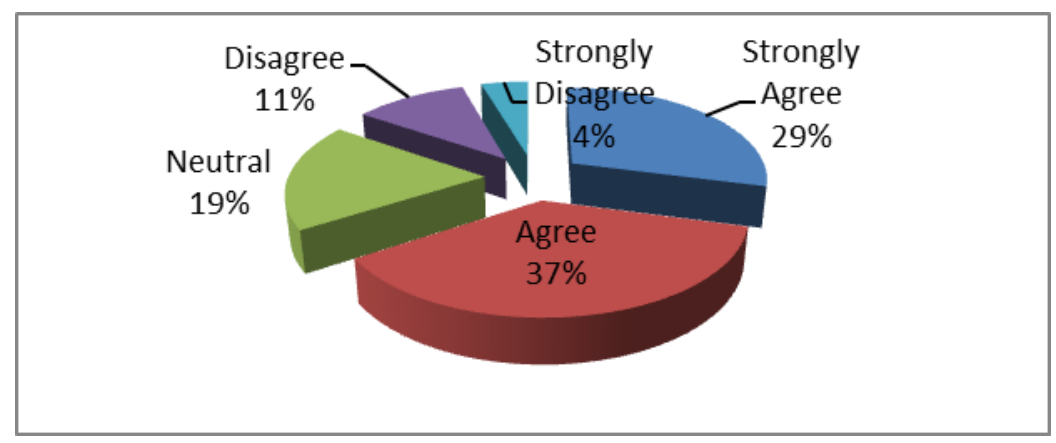

Figure 5: the use of e- e-learning is more flexible than the traditional way of teaching

Figure 5 illustrates that (66\%) of teachers agree that using e-learning can be more flexible than the traditional way of teaching. Only $(15 \%)$ felt that e-learning is not more flexible than the conventional way of teaching.

Finally, the teachers were asked whether they believe that e-learning could contribute to solving some educational problems (such as increasing the number of students, access to distance learning materials, increases students' access to education, etc.) 


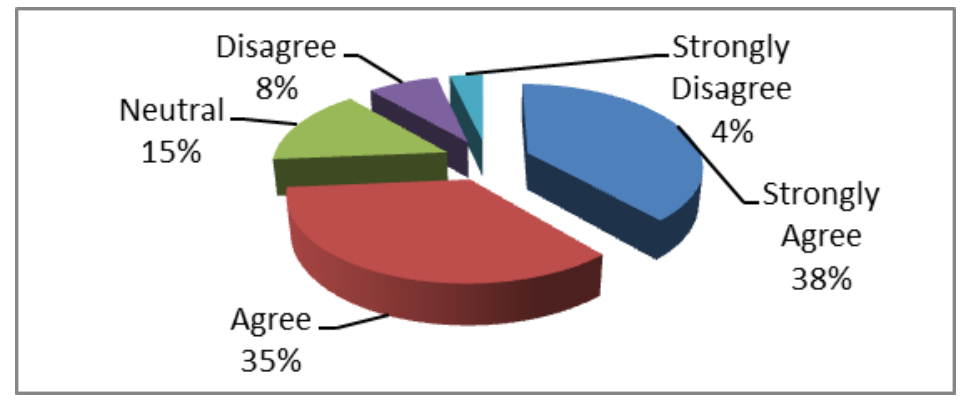

Figure 6: the use of e-learning can contribute to solving some educational problems

The results suggested that $(73 \%)$ teachers believe that e-learning can contribute to solving some educational problems. (15 $\%)$ were still undecided, and only a small number that is $(12 \%)$ responded negatively.

\section{Examining the association between demographic variables and attitude towards e-learning}

The second research question was, "Is there any association between demographic characteristics including teaching experience, age, gender, computers use, academic area and tutors' attitude towards e-learning?". In this context, the present section analyses the role of (gender, age, teaching experience, academic area, and computer use) on perception and attitude of academic staff towards e-learning. Chi-square and Person correlation were applied to explore the association of variables.

\section{i. Gender and instructors' attitudes toward e-learning}

This section of the study investigates whether there is a significant association between the gender of participants and using elearning by exploring the following hypotheses:

$\mathrm{H}_{0}$ : There is no significant association between the gender of participants and their attitudes using e-learning.

$\mathrm{H}_{1}$ : There is a significant association between the gender of participants and using e-learning.

Table 2: Gender and instructors' attitudes toward e-learning

Chi-Square Tests

\begin{tabular}{|c|c|c|c|c|c|}
\hline & Value & $\mathrm{df}$ & Asymp. Sig. (2-sided) & Exact Sig. $\quad$ (2-sided) & Exact Sig. (1-sided) \\
\hline Pearson Chi-Square & $7.735^{\mathrm{a}}$ & 1 & .005 & & \\
\hline Continuity Correction $^{\mathrm{b}}$ & 6.947 & 1 & .008 & & \\
\hline Likelihood Ratio & 7.969 & 1 & .005 & & \\
\hline Fisher's Exact Test & & & & .006 & .004 \\
\hline Linear-by-Linear Association & 7.700 & 1 & .006 & & \\
\hline $\mathrm{N}$ of Valid Cases & 219 & & & & \\
\hline
\end{tabular}

a. 0 cells $(.0 \%)$ have expected count less than 5 . The minimum expected count is 29.56.

b. Computed only for a $2 \times 2$ table

As shown in Table (2), the results confirm the alternative hypothesis (H1), and prove that there was a significant association between the gender of participants and using E-learning (P.value=0.005).

\section{ii. Age and teachers' attitudes toward e-learning}

To investigate whether there is a significant correlation between the age of participants and using e-learning, the following hypotheses were explored using person correlation test.

$\mathrm{H}_{0}$ : There is no significant correlation between the age of participants and using e-learning

$\mathrm{H}_{1}$ : There is a significant correlation between the age of participants and using e-learning

Table 3: Age and instructors' attitudes toward e-learning

Correlations

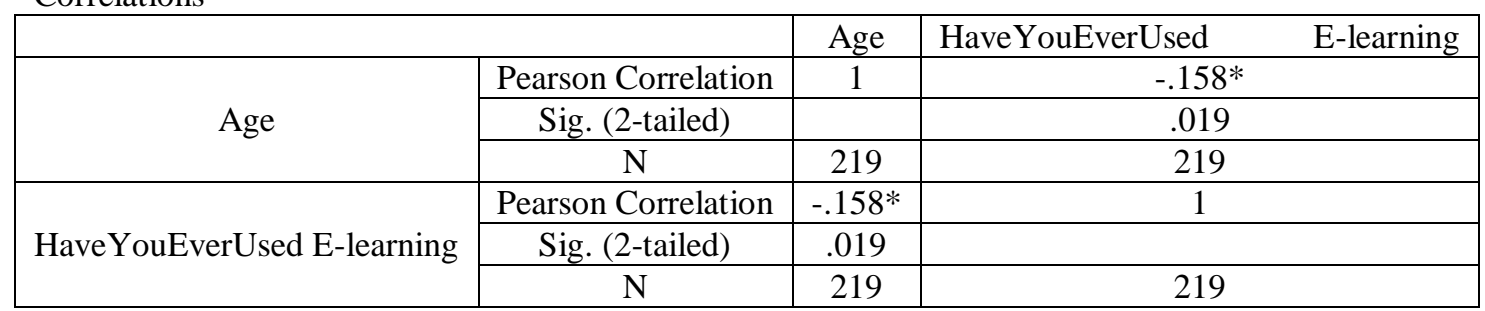

*. Correlation is significant at the 0.05 level (2-tailed). 
Citation: Khalid Ramadan, et al., Investigating Instructors' Attitude towards the Adoption of E-Learning Technology in Libyan Higher Education Institutes: Case Study; Misurata University. Australian Journal of Basic and Applied Sciences, 13(5): 43-54. DOI: 10.22587/ajbas.2019.13.5.5

As shown in Table (3), the results confirm the alternative hypothesis (H1), and prove that there was a negative significant correlation between the age of participants and using e-learning (P.value $=0.019)$.

\section{iii. Educational experience and teachers' attitudes toward e-learning}

This section of the study investigated whether there is a significant correlation between using e-learning and the years of teaching experience that participants possess. The Pearson correlation test was conducted to explore the following hypotheses:

$\mathrm{H}_{0}$ : There is no significant association between using e-learning and teaching experience

$\mathrm{H}_{1}$ : There is a significant association between using e-learning and the teaching experience

Table 4: Teaching experience and instructors' attitudes toward e-learning.

Correlations

\begin{tabular}{|c|c|c|c|}
\hline \multicolumn{2}{|c|}{} & $\begin{array}{c}\text { Teaching } \\
\text { Experience }\end{array}$ & $\begin{array}{c}\text { HaveYouEverUsed } \\
\text { E-learning }\end{array}$ \\
\hline \multirow{3}{*}{\begin{tabular}{c} 
TeachingExperience \\
\cline { 2 - 4 }
\end{tabular}} & Pearson Correlation & 1 & $-.199^{* *}$ \\
\cline { 2 - 4 } & Sig. (2-tailed) & & .003 \\
\cline { 2 - 4 } $\begin{array}{c}\text { HaveYouEverUsed E- } \\
\text { learning }\end{array}$ & N & 219 & 219 \\
\cline { 2 - 4 } & Pearson Correlation & $-.199^{* *}$ & 1 \\
\cline { 2 - 4 } & Sig. (2-tailed) & .003 & 219 \\
\hline
\end{tabular}

**. Correlation is significant at the 0.01 level (2-tailed).

As shown in Table (4), the results affirm the alternative hypothesis (H1) and prove that there was a significant negative correlation between the years of teaching experience and using e-learning (P.value $=0.003$ ).

\section{iii. Major and teachers' attitudes toward e-learning}

This section of the study investigates whether there is a significant association between the disciplines ofthe participant and using e-learning.

Table 5: Major and instructors' attitudes toward e-learning

Chi-Square Tests

\begin{tabular}{|c|c|c|c|c|c|}
\hline & Value & $\mathrm{df}$ & $\begin{array}{c}\text { Asymp. Sig. } \\
(2 \text {-sided })\end{array}$ & $\begin{array}{c}\text { Exact Sig. } \\
(2 \text {-sided })\end{array}$ & $\begin{array}{c}\text { Exact Sig. } \\
(1 \text {-sided })\end{array}$ \\
\hline Pearson Chi-Square & $59.958^{\mathrm{a}}$ & 1 & .000 & & \\
\hline Continuity Correction $^{\mathrm{b}}$ & 57.768 & 1 & .000 & & \\
\hline Likelihood Ratio & 68.629 & 1 & .000 & & .000 \\
\hline Fisher's Exact Test & & & & & \\
\hline $\begin{array}{c}\text { Linear-by-Linear } \\
\text { Association }\end{array}$ & 59.685 & 1 & .000 & & \\
\hline N of Valid Cases & 219 & & & & \\
\hline
\end{tabular}

a. 0 cells $(.0 \%)$ have expected count less than 5. The minimum expected count is 33.12 .

b. Computed only for a $2 \times 2$ table

As shown in Table (5), the results revealed that there was a significant association between the disciplines of participants and using E-learning $(\mathrm{P}$. value $=0.000)$.

\section{vi. Computer use and teachers' attitudes toward e-learning}

The results, as shown in the above table, also reveals that there was a a significant positive correlation between the years of computer use and using E-learning (P.value=0.000). See Table (6)

Table 6: Computer use and teachers' attitudes toward e-learning Correlations

\begin{tabular}{|c|c|c|c|}
\hline & & Years Of Computer Use & Have You Ever Used E-learning \\
\hline \multirow{3}{*}{ Years Of Computer Use } & Pearson Correlation & 1 & $.285^{* *}$ \\
\hline & Sig. (2-tailed) & & .000 \\
\hline & $\mathrm{N}$ & 219 & 219 \\
\hline \multirow{3}{*}{ Have You Ever Used E-learning } & Pearson Correlation & $.285^{* *}$ & 1 \\
\hline & Sig. (2-tailed) & .000 & \\
\hline & $\mathrm{N}$ & 219 & 219 \\
\hline
\end{tabular}

\footnotetext{
**. Correlation is significant at the 0.01 level (2-tailed).
} 
Citation: Khalid Ramadan, et al., Investigating Instructors' Attitude towards the Adoption of E-Learning Technology in Libyan Higher Education Institutes: Case Study; Misurata University. Australian Journal of Basic and Applied Sciences, 13(5): 43-54. DOI: 10.22587/ajbas.2019.13.5.5

\section{DISCUSSION}

It is generally argued that educators' attitudes, perception, and engagement play the main role in the success of the adoption and integrating technology in the teaching-learning process(Bahiti \& Farizi, 2018; Dong \& Zhang, 2011; Karaca, Can, \& Yildirim, 2013; Onasanya, Shehu, Oduwaiye, \& Shehu, 2010; Xhaferi et al., 2018; Yilmaz \& Bayraktar, 2014).In this context, this study examined the attitude of academic staff towards e-learning, it also investigated the impact of some demographic characteristics on the tutors' perception and attitudes. Generally, the findings revealed that the academic staff in MU had positive attitudes towards-learning, as they think the adoption of e-learning in MU will positively impact on students' performance and engagement. The results of this study were consistent with a number of similar previous studies (Abod-her, 2013; Bendania, 2011; Concannon, Flynn, \& Campbell, 2005; Elzawi, A., Wade, S., Kenan, T., \& Pislaru, 2013; Jamlan, 2004; Liaw et al., 2007; Mahmoud, S. R., El Magrabi, N. M., \& Mohamed, 2015; Ransom, Graham, \& Mott, 2007; Reading, 2008).

The results also indicated that gender seems to play a vital role in the teacher's response towards e-learning, whereas there was a significant difference regarding the teacher's attitude towards e-learning based on gender. It was found that the males were more likely to adopt e-learning in their teaching than their counterparties, i.e., females. This particular finding could provide new insights into the role of gender on attitudes toward e-learning. Nevertheless, this result contrasts with previously related researches(Bahiti \& Farizi, 2018; Bakr, 2011; Bassfar, Z., Rozinah, J., \& Merza, 2012; Idris \& Osman, 2017). These conflicting results could be interpreted by the fact that educators in MU characterized by some factors that affected their attitudes, including limited technology access, skill, resistant to change and interest. Moreover, this study conducted with various samples of participants with different cultures in a different environment and context.

Additionally, in regards to age, there was a significant difference between the participants' attitudes involved in the present study based on age. It was revealed that the tutors with relatively older age are less confident with the harness of e-learning in their educational activities, and they also had negative attitudes toward e-learning. The result was not surprising because it contrasted with the previous related studies (Bassfar, Z., Rozinah, J., \& Merza, 2012) who they found no significant correlation between using technology and age of teachers.

The conflicting result could be interpreted by the fact that these studies were conducted with different samples of participants with different cultures in a different environment and context.

In terms of teaching experience, the results reported a statistically significant difference between educators' attitudes based on their educational experience. It disclosed that the tutors with relatively long years of experience are less familiar with e-learning practices. These results come in line with (Karaca et al., 2013; Shin, 2010; Tuparova et al., 2006) who declared that the years of educational experience were negatively associated with the harness of technology in education. This was also supported by ( Kisanga, 2015) who affirmed that a significant negative correlation between instructor attitudes towards technology integration in teaching and years of the educational experience.

On the contrary(Shin, 2010; Xhaferi, Farizi and Bahiti, 2018a) found that the years of teaching experiences were positively associated with the use of technology in education.

Data on experience with computer use revealed that there was a statistically significant difference in attitudes towards elearning based on computer use experience. This result showed that tutors who had more experience in computer use had more positive attitudes towards e-learning than those with less experience in computer use. This outcome agrees with results from several scholars including (Panda and Mishra, 2007; Cavas et al., 2009; Krishnakumar and Kumar, 2011; Karaca, Can and Yildirim, 2013), which found an association between experience with computer use and attitude towards e-learning. In this context, computer use knowledge acted as a powerful role in constructing positive attitudes towards e-learning, i.e. the more profound familiarity with computer systems use lead to a more positive attitude towards e-learning.

Finally, the study also examined the influence of the academic area of research participants, particularly about the adoption of e-learning in delivering lectures. The results revealed that there was a statistically significant difference between tutors' science major and tutors' art major.

Also, the results showed that tutors' science discipline had more favorable attitudes towards e-learning than those with art discipline. This result concurs with the study conducted by (Angadi, 2014). This finding owed to the reason that the instructors in the art discipline didn't attend any ICT courses or trained to use it for teaching.

\section{CONCLUSION}

In conclusion, the results of this study reveal that the tutors of Misurata University are in favor of adopting e-learning. It indicated that the majority of participants feel confident in the use of ICT facilities and enjoy the harness of e-learning in teaching, believe in the advantages of e-learning and are interested in developing e-learning courses in their teaching process.

The findings also reaffirm the significance of considering tutors' demographic characteristics differences when harnessing elearning in learning activities.

It is recommended that proper training and supporting could supply educators with effective accessibility to ICT facilities and further enhancing their skills, knowledge, and awareness on benefits from e-learning technology. In light of this, their perceptions and attitudes towards e-learning could improve significantly, contributing to the implementation of e-learning successfully in LHLIs. 
Citation: Khalid Ramadan, et al., Investigating Instructors' Attitude towards the Adoption of E-Learning Technology in Libyan Higher Education Institutes: Case Study; Misurata University. Australian Journal of Basic and Applied Sciences, 13(5): 43-54. DOI: 10.22587/ajbas.2019.13.5.5

\section{REFERENCES}

Abod-her. (2013). Impacts of globalization and awareness of higher education policy in adoption and use of ICT in Libyan universities (Doctoral dissertation, University of Huddersfield).

Ahern, N., \& Wink, D. M. (2010). Virtual Learning Environments. Nurse Educator (Vol. 35). https://doi.org/10.1097/NNE.0b013e3181f7e943.

Ahmed, T. T. (2013). Toward Successful E-Learning Implementation in Developing Countries: A Proposed Model for Predicting and Enhancing Higher Education Instructors' Participation. International Journal of Academic Research in Business and Social Sciences, 3(1), 2222-6990.

Al-Adwan, A., Al-Adwan, A., \& Smedley, J. (2013). Exploring students acceptance of e-learning using Technology Acceptance Model in Jordanian universities, 9(2013), 4-18. https://doi.org/10.1504/IJHTM.2015.074538

Al-Azawei, A., Parslow, P., \& Lundqvist, K. (2016). Barriers and opportunities of e-learning implementation in Iraq: A case of public universities. International Review of Research in Open and Distance Learning, 17(5), 126-146. https://doi.org/10.19173/irrodl.v17i5.2501

Andersson, A., \& Grönlund, Å. (2009). A Conceptual Framework for E-Learning in Developing Countries: A Critical Review of Research Challenges. The Electronic Journal of Information Systems in Developing Countries, 38(1), 1-16. https://doi.org/10.1002/j.1681-4835.2009.tb00271.x

Angadi, G. R. (2014). Teachers' Attitude towards Information and Communication Technology (ICT) Dst. International Journal of Education and Psychological Research (IJEPR, 3(1), 325-336.

Bahiti, R., \& Farizi, A. (2018). Investigation of Lecturer' Attitudes towards E-Learning According to Demographic Variables. European Journal of Formal Sciences and Engineering, 1(1), 11. https://doi.org/10.26417/ejfe.v1i1.p11-16

Bakr, S. M. (2011). Attitudes of Egyptian Teachers towards Computers. Contemporary Educational Technology, 2(4), 308-318.

Bassfar, Z., Rozinah, J., \& Merza, A. (2012). Investigate the Self-efficacy and Attitudes of Teachers towards e-learning in Saudi Arabia. International Journal of Scientific \& Engineering Research, 3(6), 1-4.

Bendania, A. (2011). INSTRUCTORS' AND LEARNERS' ATTITUDES TOWARD TEACHING AND LEARNING ONLINE: KING FAHD UNIVERSITY OF PETROLEUM AND MINERALS (KFUPM) (SAUDI ARABIA) CASE STUDY ProQuest. International Journal of Arts and Sciences, 4(8), 223-241.

Bhuasiri, W., Xaymoungkhoun, O., Zo, H., Rho, J. J., \& Ciganek, A. P. (2012). Critical success factors for e-learning in developing countries: A comparative analysis between ICT experts and faculty. Computers and Education, 58(2), 843-855. https://doi.org/10.1016/j.compedu.2011.10.010

Cavas, B., Cavas, P., Karaoglan, B., \& Kisla, T. (2009). A Study on Science Teachers' Attitudes Toward Information and Communications Technologies in Education.. ERIC2)8,).

Clayton, J., Elliott, R., Saravani, S.-J., Greene, N., \& Huntington, N. (2008). e-Learning in industry: A summary of activities.

Concannon, F., Flynn, A., \& Campbell, M. (2005). What campus-based students think about the quality and benefits of e-learning. British Journal of Educational Technology, 36(3), 501-512. https://doi.org/10.1111/j.1467-8535.2005.00482.x

Dečman, M. (2015). Modeling the acceptance of e-learning in mandatory environments of higher education: The influence of previous education and gender. Computers in Human Behavior, 49. https://doi.org/10.1016/j.chb.2015.03.022

Denis, N. (2014). E-learning for University Effectiveness in the Developing World. Global Journal of Human-Social Science ..., $14(3)$.

Dong \& Zhang, 2011. (2011). Gender differences in adoption of information systems: New findings from China. Elsevier.

Educational digital technologies in developing countries challenge third party providers. (n.d.). https://doi.org/10.2307/jeductechsoci.19.3.121

Elkaseh, A., Wong, K. W., \& Fung, C. C. (2015). A Review of the Critical Success Factors of Implementing e-Learning in Higher Education. The International Journal of Technologies in Learning, 22(2), 1-13. https://doi.org/10.18848/23270144/CGP/v22i02/49160

Elliott, R., \& Clayton, J. (2007). E-learning activity in New Zealand industry training organisations: Perceived benefits and barriers. Ascilite, (June), 244-248.

Elzawi, A., Wade, S., Kenan, T., \& Pislaru, C. (2013). Exploratory study of the attitudes of academic staff in Libyan Universities towards the role of the Internet. 8th International Conference for Internet Technology and Secured Transactions (ICITST2013) (Pp. 490-493). IEEE, 490-493.

Flood, J. (2002). E-learning - a driver for Continuing Professional Development ? Director of Learning, (2), 6-8.

Idris, F. elmoula A. alla, \& Osman, Y. (2017). Implementation of E-learning in The University of Gezira Barriers and Opportunities. Educational Science and Research, 1(1), 24-35. https://doi.org/10.22496/esr2016090470

Jamlan, M. (2004). Faculty opinions towards introducing e-learning at the University of Bahrain. International Review of Research in Open and Distance Learning, 5(2).

Karaca, F., Can, G., \& Yildirim, S. (2013). Technology utilisation in elementary schools in Turkey's capital: A case study. Educational Studies, 39(5), 552-567. https://doi.org/10.1080/03055698.2013.807726

Kenan, T., \& Pislaru, C. (2012). Challenges related to the implementation of e-learning in higher education institutions in Libya. In Proceedings of The Queen's Diamond Jubilee Computing and Engineering Annual Researchers' Conference 2012: CEARC'12. (pp. 116-122). 
Citation: Khalid Ramadan, et al., Investigating Instructors' Attitude towards the Adoption of E-Learning Technology in Libyan Higher Education Institutes: Case Study; Misurata University. Australian Journal of Basic and Applied Sciences, 13(5): 43-54. DOI: 10.22587/ajbas.2019.13.5.5

Kenan, Thuraya, Pislaru, C., \& Elzawi, A. (2014). Trends and Policy Issues for the e-Learning Implementation in Libyan Universities. International Journal of Trade, Economics and Finance, 105-109. https://doi.org/10.7763/IJTEF.2014.V5.349

Kisanga, D. (2015). Investigation of attitudinal factors towards the transition from face-to-face e-learning in Tanzanian higher learning institutions: a mixed methods approach, 402.

Kisanga, D. H. (2016). Determinants of teachers' attitudes towards e-learning in Tanzanian higher learning institutions. International Review of Research in Open and Distance Learning, 17(5), 109-125. https://doi.org/10.19173/irrodl.v17i5.2720

Krishnakumar and Kumar (2011). (2011). Attitude of Teachers' of Higher Education towards e-Learning. Journal of Education and Practice, 2(4), 7.

Kwofie \& Henten, 2011. (2011). 3 RD WORLD CONFERENCE ON EDUCATIONAL SCIENCES Bahcesehir University , Conference Centre Istanbul - Turkey Held on 3 rd February, 2011 Presenters Benjamin Kwofie \& Prof . Anders Henten.

Li, L., Cheng, L., on, K. Q.-2008 I. C., \& 2008, U. (2008). An e-learning system model based on affective computing. Ieeexplore.Ieee.Org.

Li, L., Cheng, L., \& On, K. Q. (2008). An e-learning system model based on affective computing. Ieeexplore.Ieee.Org.

Liaw, S. S., Huang, H. M., \& Chen, G. D. (2007). Surveying instructor and learner attitudes toward e-learning. Computers and Education, 49(4), 1066-1080. https://doi.org/10.1016/j.compedu.2006.01.001

Mahmoud, S. R., El Magrabi, N. M., \& Mohamed, F. R. (2015). Faculty of Nursing Teaching Staff members and Students Attitudes toward e-learning. IOSR Journal of Nursing and Health Science, 4(4), 2320-1940. https://doi.org/10.9790/195904463645

MASON, R. \& RENNIE, F. (2006). Elearning: The Key Concepts - Robin Mason, Frank Rennie.

Miliszewska, I., \& Miliszewska, I. (2009). Effective transnational education programs : concepts, dimensions, perspectives. Vdm Verlag Dr. Müller.

Onasanya, S. A., Shehu, R. A., Oduwaiye, R. O., \& Shehu, L. A. (2010). Higher Institutions Lecturers' Attitude Towards Integration of ICT into Teaching and Research in Nigeria. Research Journal of Information Technology, 2(1), 1-10. https://doi.org/10.3923/rjit.2010.1.10

Othman. (2009). Investigating an On-line Teaching and Learning Environment for the University of Omar Al-Mukhtar, Libya Partial fulfilment of the requirements for the Master degree of Information System Management.

Othman, A., Pislaru, C., Kenan, T., \& Impes, A. (2013). Analysing the Effectiveness of IT Strategy in Libyan Higher Education Institutes. International Journal of Digital Information and Wireless Communications (IJDIWC), 3(3), $114-129$.

Panda, S., \& Mishra, S. (2007). E-Learning in a Mega Open University: Faculty attitude, barriers and motivators. Educational Media International, 44(4), 323-338. https://doi.org/10.1080/09523980701680854

Pilli, F. \& A.-M. (2014). Investigating the Students 'Attitude Toward the use of E-Learning in Girne American University. International Journal of Business and Social Science, 5(5), 169-175.

Pynoo, B., Tondeur, J., Braak, J. Van, ... W. D.-C. \&, \& 2012, undefined. (n.d.). Teachers' acceptance and use of an educational portal. Elsevier.

Ransom, W., Graham, C., \& Mott, J. (2007). Faculty perceptions of technology projects. Educause Quarterly.

Reading, C. (2008). Recognising and measuring engagement in ICT-rich learning environments. Australian Council for Computers in Education.

Rhema, A., \& Miliszewska, I. (2010). Towards E-Learning in Higher Education in Libya. Issues in Informing Science and Information Technology, 7, 423-437. https://doi.org/10.28945/1218

Rhema, A., Miliszewska, I., \& Sztendur, E. M. (2013). Attitudes towards e-Learning and Satisfaction with Technology among Engineering Students and Instructors in Libya. Proceedings of Informing Science \& IT Education Conference, 15.

Rogers, E. M. (2003). Diffusion of innovations, edn. Free Pres., New York.

Sangrà, a, Vlachopoulos, D., Cabrera, N., \& Bravo, S. (2011). Towards an Inclusive Definition of E-Learning.

Sangrà, A., Vlachopoulos, D., \& Cabrera, N. (2012). Building an inclusive definition of e-learning: An approach to the conceptual framework. International Review of Research in Open and Distance Learning, 13(2), 145-159. https://doi.org/10.19173/irrodl.v13i2.1161

Selim, H. M. (2007). Critical success factors for e-learning acceptance: Confirmatory factor models. Computers and Education, 49(2), 396-413. https://doi.org/10.1016/j.compedu.2005.09.004

Shin, W. S. (2010). Individual and Organizational Factors Influencing.

Sife, A., Lwoga, E., \& Sanga, C. (2007). New technologies for teaching and learning: Challenges for higher learning institutions in developing countries. International Journal of Education and Development Using Information and Communication Technology, Vol. 3(2), 57-67.

Suri, G, \& Sharma, S. (2016). Investigation of Teacher's Attitude towards e-learning-A case Study of Panjab University, Chandigarh, India. Gjimt.Ac.In3)6,).

Suri, Gunamala, \& Sharma, S. (2013). The Impact of Gender on Attitude Towards Computer Technology and E- Learning: An Exploratory Study of Punjab University, India. International Journal of Engineering Research, 2(2319-6890), 22.

Tamtam, A., Gallagher, F., Olabi, A. G., \& Naher, S. (2011). Higher education in Libya, system under stress. In Procedia - Social and Behavioral Sciences (Vol. 29, pp. 742-751). https://doi.org/10.1016/j.sbspro.2011.11.300

Tarus, J. K., Gichoya, D., \& Muumbo, A. (2015). Challenges of implementing E-learning in Kenya: A case of Kenyan public universities. International Review of Research in Open and Distance Learning, 16(1), 120-141. https://doi.org/10.19173/irrodl.v16i1.1816 
Teo, T, Ursavaş, O. F., \& Bahçekapili, E. (2012). An assessment of pre-service teachers' technology acceptance in Turkey: A structural equation modeling approach. Asia-Pacific Education Researcher, 21, 191-202.

Teo, Timothy. (2011). Factors influencing teachers' intention to use technology: Model development and test. Computers \& Education, 57(4), 2432-2440. https://doi.org/10.1016/J.COMPEDU.2011.06.008

Thomas, M. (2009). Virtual learning environments: Using, choosing and developing your VLE - By Martin Weller. British Journal of Educational Technology (Vol. 40). https://doi.org/10.1111/j.1467-8535.2009.01026_11.x

Tuparova, D., Tuparov, G., Ivanov, S., Karastranova, E., \& Peneva, J. (2006). Teachers ' attitude towards e-learning courses in Bulgarian universities. Current Developments in Technology-Assisted Education, 1755-1759.

Wagner, N., Hassanein, K., \& Head, M. (2008). Who is responsible for e-learning success in higher education? A stakeholders' analysis. Journal of Educational Technology \& Society, 11(3), 26-36.

Welsh, E. T., Wanberg, C. R., Brown, K. G., \& Simmering, M. J. (2003). E-learning: emerging uses, empirical results and future directions. International Journal of Training and Development, 7(4), 245-258. https://doi.org/10.1046/j.13603736.2003.00184.x

Xhaferi, G., Farizi, A., \& Bahiti, R. (2018). Teacher' attitudes towards e-learning in higher education in Macedonia Case study: University of Tetovo. European Journal of Electrical Engineering and Computer Science, $2(5), 14-17$. https://doi.org/10.24018/ejece.2018.2.5.26

Yilmaz, O., \& Bayraktar, D. M. (2014). Teachers' Attitudes towards the Use of Educational Technologies and their Individual Innovativeness Categories. Procedia - Social and Behavioral Sciences, 116, 3458-3461. https://doi.org/10.1016/j.sbspro.2014.01.783 